IZA DP No. 9391

The Japanese Labour Market during the Global Financial Crisis and the Role of Non-Standard Work: A Micro Perspective

Alexander Hijzen

Ryo Kambayashi

Hiroshi Teruyama

Yuji Genda

September 2015 


\title{
The Japanese Labour Market during the Global Financial Crisis and the Role of Non-Standard Work: A Micro Perspective
}

\author{
Alexander Hijzen \\ $O E C D$ and IZA \\ Ryo Kambayashi \\ Hitotsubashi University \\ Hiroshi Teruyama \\ Kyoto University \\ Yuji Genda \\ University of Tokyo
}

\section{Discussion Paper No. 9391 \\ September 2015}

\author{
IZA \\ P.O. Box 7240 \\ 53072 Bonn \\ Germany \\ Phone: +49-228-3894-0 \\ Fax: +49-228-3894-180 \\ E-mail: iza@iza.org
}

\begin{abstract}
Any opinions expressed here are those of the author(s) and not those of IZA. Research published in this series may include views on policy, but the institute itself takes no institutional policy positions. The IZA research network is committed to the IZA Guiding Principles of Research Integrity.

The Institute for the Study of Labor (IZA) in Bonn is a local and virtual international research center and a place of communication between science, politics and business. IZA is an independent nonprofit organization supported by Deutsche Post Foundation. The center is associated with the University of Bonn and offers a stimulating research environment through its international network, workshops and conferences, data service, project support, research visits and doctoral program. IZA engages in (i) original and internationally competitive research in all fields of labor economics, (ii) development of policy concepts, and (iii) dissemination of research results and concepts to the interested public.
\end{abstract}

IZA Discussion Papers often represent preliminary work and are circulated to encourage discussion. Citation of such a paper should account for its provisional character. A revised version may be available directly from the author. 


\section{ABSTRACT \\ The Japanese Labour Market during the Global Financial Crisis and the Role of Non-Standard Work: A Micro Perspective}

This paper analyses aggregate labour dynamics during the global financial crisis in Japan and the role of nonstandard work using micro data. The analysis proceeds in two steps. First, using comprehensive establishment-level datasets for the period 1991-2009, it provides a detailed portrait of the adjustment behaviour of establishments at the micro level. Second, it compares aggregate labour market dynamics during the global financial crisis with that observed during the 1997 crisis and decomposes the observed differences into components that can be attributed to changes in the micro-adjustment behaviour of Japanese establishments, changes in the incidence of non-standard work and changes in the distribution of shocks across establishments. It finds that the incidence of non-standard work has increased considerably, worker turnover is much higher among non-standard than standard workers and adjustments in working-time are less important for non-standard workers. Counterfactual simulations suggest that the employment response during the global crisis would have been smaller if the incidence of non-standard work remained at the level observed during the 1997 crisis. The relatively small employment response observed during the global financial crisis is therefore driven by factors others than the increase in the incidence of non-standard work.

JEL Classification: D22, E24, J23, J41

Keywords: labour market duality, labour market resilience, job quality, temporary work, crisis

Corresponding author:

Ryo Kambayashi

Institute of Economic Research

Hitotsubashi University

2-1 Naka, Kunitachi

Tokyo 186-8603

Japan

E-mail: kambayas@ier.hit-u.ac.jp 


\section{Introduction}

During the global financial crisis, the Japanese labour market exhibited a remarkable resilience. This is most clearly illustrated by the low responsiveness of the unemployment rate to the decline in aggregate demand during the crisis, both in comparison with other countries as well as with historical experience. For example, OECD (2012) shows that the response of the unemployment rate to the decline in GDP during the crisis in Japan was among the lowest observed in the OECD area. In addition, the unemployment impact of the crisis also appears to be smaller than what might have been suggested on the basis of recent patterns. ${ }^{1}$

The unemployment response to the decline in output in Japan was widely expected to be small relative to most other OECD countries since this has been consistently the case during previous recessionary episodes. To some extent, this reflects the importance of the long-term employment system which tends to be associated with a strong commitment by employers to preserve jobs during periods of slack aggregate demand. ${ }^{2}$ However, the unemployment response was even smaller than expected by professional forecasters and economic observers and seemingly inconsistent with the growing sensitivity of unemployment to outputs shocks during the past 20 years. Indeed, the Japanese labour market had been subject to ${ }^{3}$ important structural changes since the collapse of the bubble in 1992. The most notable of these was the increase in the incidence of non-standard work, in part as a result of the gradual liberalisation of the market for temporary work during the late 1990s, and this was seen as an important factor behind the gradual rise in the sensitivity of unemployment with respect to output shocks (Steinberg and Nakane, 2011).

The objective of is paper is to increase our understanding of aggregate labour dynamics during the global financial crisis in Japan and the role of non-standard work by using micro data. A number of

1. Dynamic forecasts based on empirical models that relate changes in the unemployment rate to changes in GDP for the period 1990Q1 to 2007Q4 predict an increase in unemployment from the start of the crisis in 2007Q4 to 2010Q4 that is 25\% larger than the actual increase. The predicted increase is 1.4 percentage points compared with an actual increase of 1.1 percentage points.

2. Moreover, the traditionally low responsiveness of unemployment to shocks is likely to be an important factor in explaining why Japan has been able to maintain low unemployment rates for such a long time, while in many other countries, particularly in Europe, cyclical rises in unemployment had a tendency to become permanent, resulting in ever higher levels of structural unemployment.

3. Actually, the economists' expectation of unemployment rate in 2009 FY was consistently larger than the actual increase.

4. Freeman and Weitzman (1986) further highlight the importance of the bonus system as a source of wage flexibility. 
previous studies have emphasised the importance of using micro data for studying aggregate dynamics in the context of firm heterogeneity or non-linearities in the adjustment behaviour of firms (e.g. Caballero et al., 1997; Davis et al., 2006; Gal et al., 2013). The use of micro data allows taking account of these factors in the present context by differentiating between changes in the adjustment behaviour of Japanese establishment at the micro level ("technology effects"), changes in the composition of workers (standard and non-standard) and establishments (size and industry) (“composition effects”) and establishmentspecific business conditions (“shock effects”).

The analysis proceeds in two steps. First, using two alternative comprehensive and nationally representative datasets of establishments for the period 1991-2009 (the Employment Trend Survey and the Monthly Labour Survey), it provides a detailed portrait of the adjustment behaviour of establishments at the micro level. Special emphasis is given to the adjustment behaviour of establishments with respect to standard and non-standard workers. Second, building on this analysis, it compares aggregate labour market dynamics during the global financial crisis with that observed during the 1997 crisis and decomposes the observed differences into components that can be attributed to changes in the micro-adjustment behaviour of Japanese establishments, changes in the incidence of non-standard work and changes in the distribution of shocks across establishments.

The remainder of this paper is structured as follows. Section 2 provides some further background on the way the Japanese labour market has developed before the crisis, and particularly on the rise in the incidence of non-standard work, and uses macro-economic data to compare the labour market adjustment pattern during the recent crisis with that during the Asian crisis. Section 3 sets out the methodological framework to analyse how establishments adjust their labour inputs and to assess the macro-economic implications of any changes in the way establishments adjust. Section 4 describes the micro level data and presents some descriptive statistics. Section 5 presents micro-economic results for the average adjustment behaviour of establishments in the cross-section as well as that across different types of establishments and workers. Section 6 analyses the role of changes in adjustment behaviour, changes in labour market composition and the nature of the shock to provide a better understanding of the aggregate labour market dynamics during the recent crisis. Section 7 concludes.

\section{Background}

\subsection{Labour market developments before the crisis and the rise of non-standard work}

Traditionally unemployment in Japan has been low and relatively insensitive to the business cycle. Figure 1 shows the evolution of the unemployment rate in Japan along with that in Germany and the 
United States since the 1970s to 2011. The comparison between Germany and Japan is particularly revealing as unemployment rates were very low in both countries in the early 1970s (around 1\%), but have evolved very differently since. Although in both countries the cyclical hikes in unemployment that followed the oil shocks of the 1970s tended to persist for a long time, resulting in gradually rising unemployment rates, the cyclical increases in unemployment were much stronger in Germany than in Japan. While in Germany the unemployment rate increased to around 4\% after the first oil shock and around $8 \%$ after the second one, the unemployment rate in Japan increased only minimally to $2 \%$ after the first oil shock and almost 3\% after the second one. As a result, the unemployment rate in Japan has been very stable and remained below 3\% until the collapse of the bubble in 1992. In sum, the Japanese labour market has been remarkably resilient in comparison with other major OECD countries during the same period.

Figure 1. Evolution of the harmonised unemployment rate in Germany, Japan and the United States Percentage of total labour force, 1970 Q1-2011 Q1

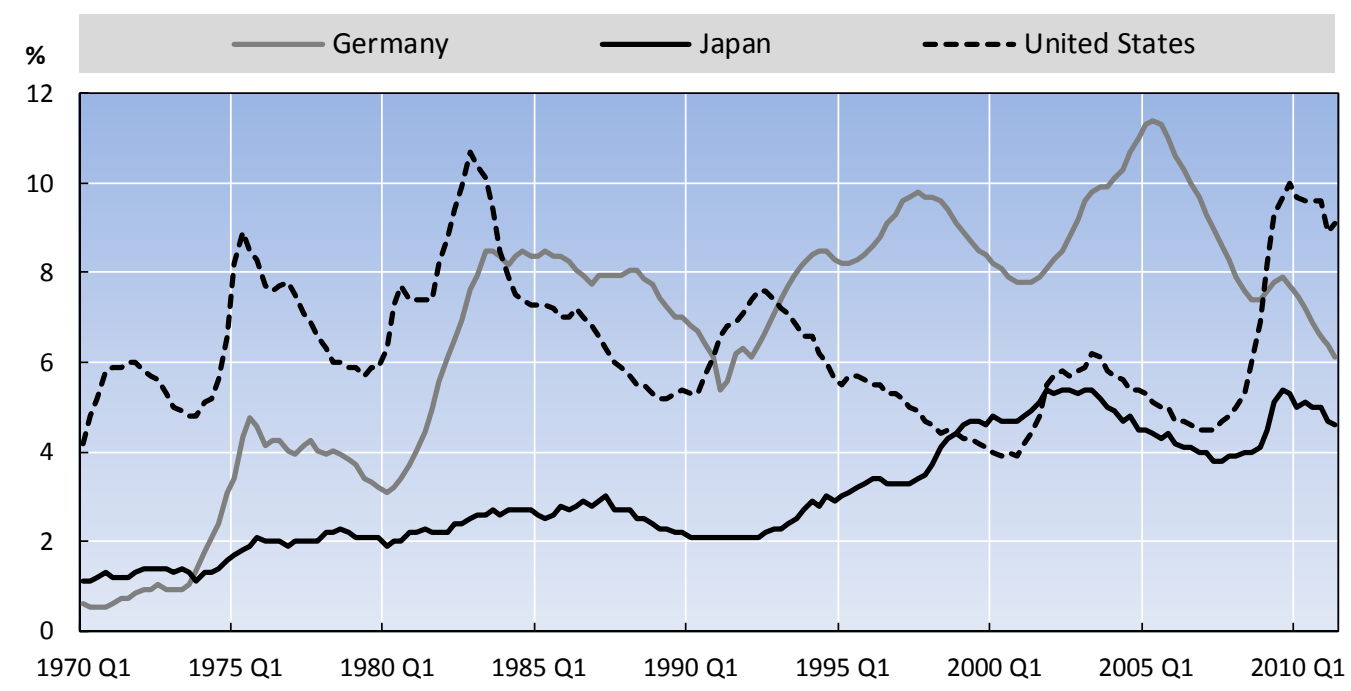

Source: OECD Main Economic Indicators Database.

The relative stability of the unemployment rate in Japan during the 1970s and 1980s partially reflects the role of strong macroeconomic performance, but also reflects the importance of the long-term employment system. The long-term employment system is characterised by two key features. First, employers are committed to maintaining stable employment levels and to avoiding layoffs in response to cyclical changes in business conditions. Rather than laying off workers, firms tend to reduce working hours 
or hoard labour at the cost of lower productivity and profitability. ${ }^{4}$ Second, the age-earnings profile is steep by international standards, resulting in strong incentives for work (Lazear, 1981; Hashimoto and Raisian, 1985). This system of "delayed payments" also reduces incentives for workers to change employer. Together these two features ensure that firms and workers have strong incentives to invest in firm-specific human capital.

However, since the collapse of the bubble in 1992, the Japanese labour market underwent a number of important structural changes that may had important implications for the level of structural unemployment as the well as the responsiveness of unemployment to economic shocks. The most visible of those is undoubtedly the rapid increase in the share of non-standard work during the "lost decade".

In Japan, two main concepts of non-standard work are used. ${ }^{5}$ The first concept is legal in nature and is based on whether a contract is open-ended or not. This is the relevant concept when considering the impact of employment-protection reforms and particularly those that govern the market for temporary work. The second concept is based on workplace titles. This includes, amongst others, part-time workers, temporary workers and dispatched workers. ${ }^{6}$ Since almost all workers with a fixed-term contract will also have a nonstandard workplace title and a substantial number of workers with non-standard workplace titles have open-ended contracts, the workplace-title concept of non-standard work tends to be broader than the legal concept. This paper focuses on the second concept since this provides a more comprehensive measure of non-standard work and is the concept that is typically used in establishment-level datasets in Japan.

Figure 2 shows the evolution of non-standard work as a share of total dependent employment using the two concepts. Data for non-standard work based on the legal concept are obtained from the basic questionnaire of the Japanese Monthly Labour Force Survey whereas data on non-standard work based on workplace titles are obtained from its Special Supplement (formerly Quarterly Supplement). It shows that non-standard work based on the legal definition was stable at about $10 \%$ up to 1996, then increased gradually to about $14 \%$ in 2002 and has been broadly stable since. The incidence of non-standard work measured in terms of workplace titles more than doubled, thus increasing considerably more quickly that the incidence of temporary work. This difference is driven by the strong increase in part-timers on openended contracts, reflecting the gradual increase in female labour force participation and the re-employment

4. Freeman and Weitzman (1986) further highlight the importance of the bonus system as a source of wage flexibility.

5. See Kambayashi and Kato (2012) for details on the recent evolution of non-standard work in Japan.

6. This concept is particularly useful when considering human-resource practices and labour conditions since Japanese labour unions have traditionally excluded workers with non-standard workplace titles. 
of retired workers. (Kambayashi and Kato, 2012). The share of non-standard work in total dependent employment increased steadily during the period 1985-1995 but started to accelerate around 1996 when the incidence of temporary work started to increase.

\section{Figure 2: The rise in non-standard work in Japan}

Percentage of dependent employment, 1985-2010

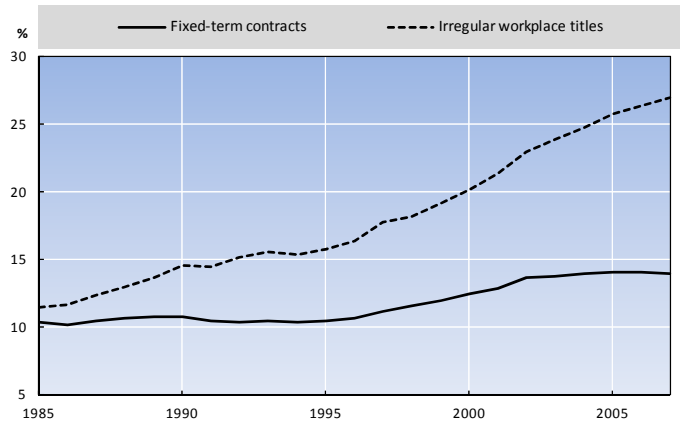

Source: Japan Statistics, Labour Force Survey, Historical data.

The usual explanation for the rise of non-standard work centres on the increased need for employment flexibility due to globalisation, technological change and increased product market competition. As a result, incentives to commit to worker-firm matches have eroded on both sides, undermining incentives to invest in firm-specific human capital, and ultimately, the effectiveness of the long-term employment system. The increased need for employment flexibility and rising concerns about the effectiveness of the long-term employment system have motivated demands for the liberalisation of the market for temporary work. This resulted in two reforms in 1996 and 1999, which gradually removed restrictions on the use of dispatched workers across occupations and sectors. ${ }^{7}$ Figure 3 relates the rise in non-standard work based on the legal definition - the appropriate definition in the context of employment protection rules - and the OECD's Employment Protection index for temporary work. It shows that the 1996 reform coincides with the start of the rise in the incidence of temporary work. ${ }^{8}$

7. Dispatched workers are persons employed by temporary worker agencies who are sent to firms on a fixedterm basis. See Okudaira, Ohtake, Kume and Tsuru (2013) for an in-depth analysis of the role of temporary work agencies in Japan.

8. According to a 2007 business survey, employment flexibility and labour costs were cited as the most important reasons for the rising incidence of non-standard work (OECD, 2011). Over 50\% of firms indicated that they hired non-standard workers to cope with fluctuations in daily or weekly demand and facilitate adjustments to business fluctuations. 
Figure 3: The rise of fixed-term contracts and the regulation of temporary contracts

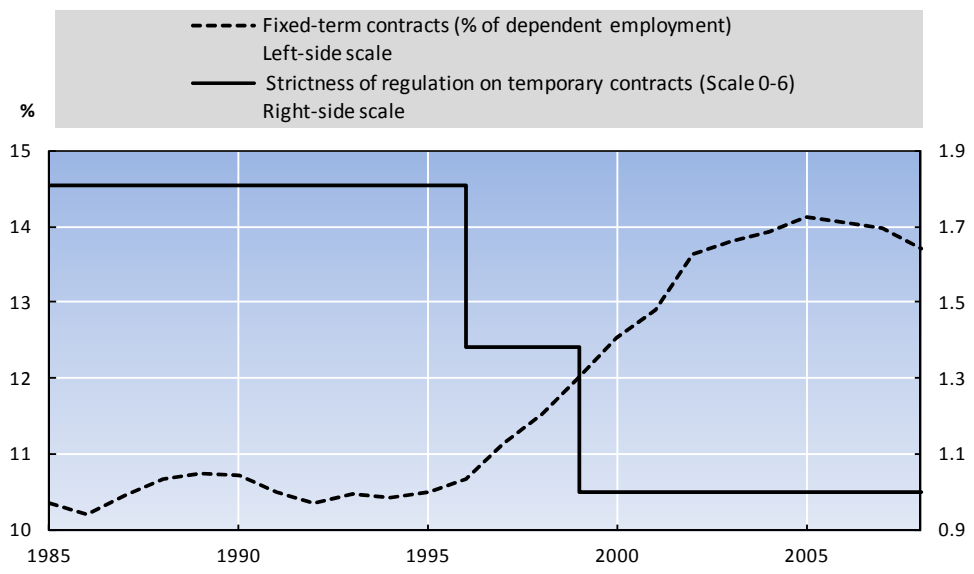

Source: Japan Statistics, Labour Force Survey, Historical data and OECD Employment Protection Database.

There has been on long-standing debate on the role of partial labour market reforms that liberalise the market for temporary work for the level of structural unemployment in Japan and elsewhere (e.g. Blanchard and Landier, 2002; Cahuc and Postel-Vinay, 2002). In countries with rigid labour markets, the increased scope for the use of temporary contracts may provide an important source of flexibility for firms and, hence, reduce adjustment costs and promote labour demand. However, in countries with low levels of structural unemployment, the main effect of such reforms may be to increase the importance of flows in and out unemployment, thereby potentially increasing the degree of frictional unemployment. While it is unlikely that the liberalisation of temporary contracts has reduced structural unemployment in Japan, it remains open to debate whether it accounts for some of the observed increase in structural unemployment.

In addition to affecting the level of structural unemployment, the increased scope for the use of temporary contracts may also have had important implications for labour market resilience. First, the relaxation of rules related to the recruitment of temporary workers reduced the cost of hiring temporary workers relative to that of permanent workers (e.g. by reducing search cost) and, by increasing the incidence of temporary work, increased the scope for making downward adjustments to temporary employment. The liberalisation of the market for temporary work may thus be expected to have increased both hires and separations of temporary workers and thereby have shifted the burden of adjustment from permanent to temporary workers. Second, the increased reliance on temporary work is likely to have reduced the pressure for making adjustments in terms of hourly wages or working hours of permanent workers (Ariga and Kambayashi, 2010; Kuroda and Yamamoto, 2013). 
In order to get a first indication of the role of the increased incidence of non-standard work during the global financial crisis, Figure 4 compares the evolution of aggregate labour market trends during the crisis of 2008-2009 (hereafter global financial crisis) with that during the crisis of 1997-1998 (hereafter 1997 crisis). We define the starting point of the economic downturn based on the turning point in GDP growth, which was in 1997Q2 for the 1997 crisis and in 2008Q4 for the global financial crisis, and track the economic adjustments during the four subsequent quarters. ${ }^{9}$ Panel A compares the change in GDP with the change in total hours worked. It shows that during both recessionary periods the decline in total hours worked significantly fell short of the decline in real GDP, reflecting the importance of labour hoarding by employers. There is some indication that the response of total hours was somewhat stronger during the latest downturn, but the differences are rather small. Panel B relates the evolution of employment since the peak in GDP to the evolution of average hours worked. This reveals a sharp contrast between the latest downturn and the 1997 crisis. While during the 1997 crisis most of the adjustment took the form of job losses during the latest crisis the bulk of the adjustment took the form of average hours reductions. Thus, if anything, the greater adjustment in terms of total hours appears to reflect the reduction in average hours worked.

9. All series are normalized to zero at the peaks of real GDP, namely 1997 Q1, and 2008 Q3. The series are seasonally adjusted using ARIMA-X(12). After taking logs, they are detrended by HP filter with smoothing parameter of 1600. Because of this adjustment, our turning point for the global financial crisis is slightly different from the official business cycle calendar by the Cabinet Office which defines the turning point as 2008Q1. The last quarter of 2008 corresponds to the collapse of Lehman which is widely seen as the starting point of the global financial crisis. We believe that for the present purposes this dating is more appropriate as it enables to us to better capture the sharp decline in aggregate demand and the subsequent adjustment in the labour market. 

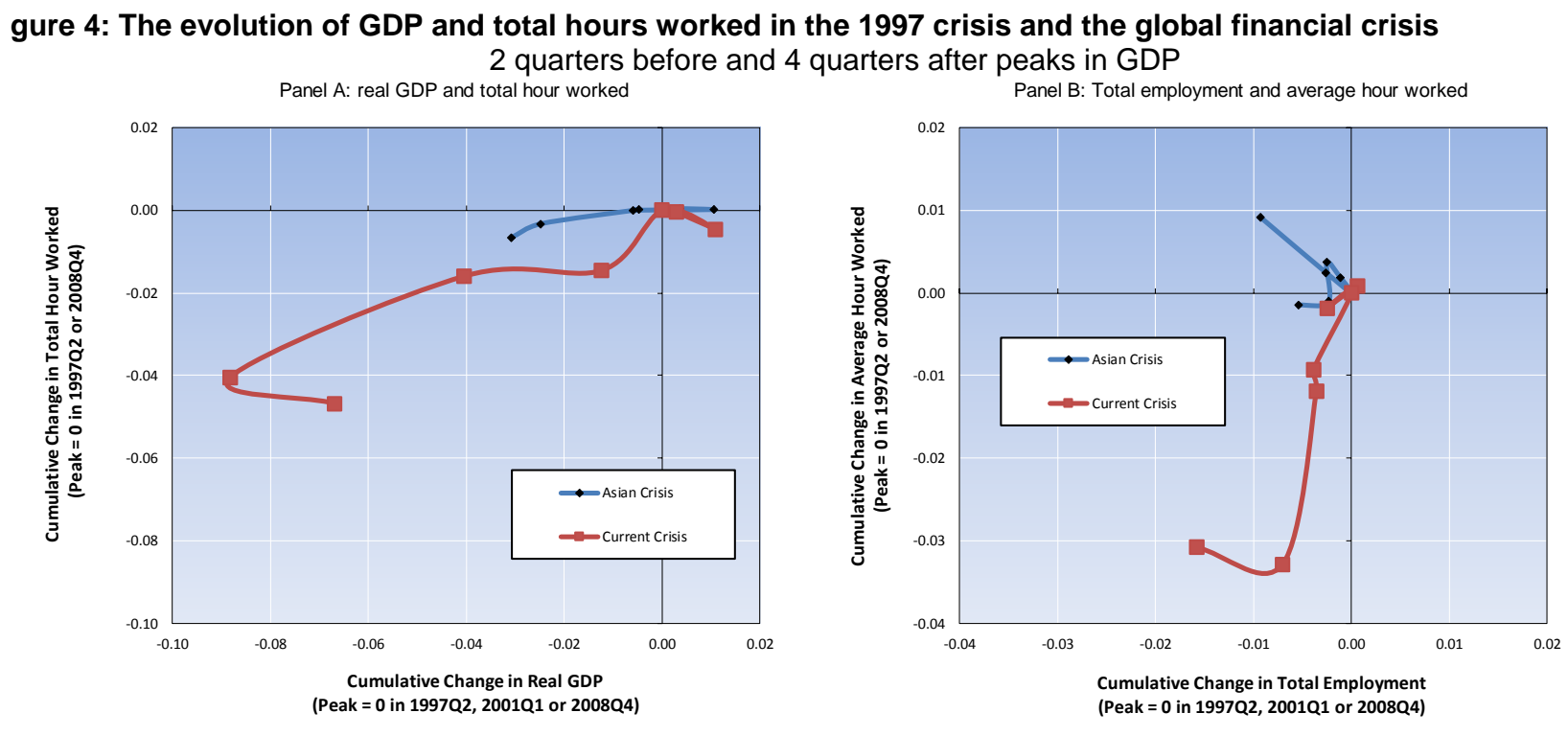

Source: OECD Main Economic Indicators Database.

The peak is 1997 Q1 for the 1997 crisis and 2008 Q3 for the global financial crisis

The limited employment response during the global financial crisis compared with that during the 1997 crisis is likely to reflect the very different nature of the recent economic downturn. While the global financial crisis originated from abroad and was transmitted to Japan mainly through a reduction in export demand in manufacturing, the 1997 crisis was the result of the collapse in domestic financial markets. Amongst other things, this is likely to have increased the importance of labour hoarding and the use of working-time reductions as responses to the global financial crisis. Hijzen and Venn (2010) provide early empirical evidence suggesting that short-time work schemes (koyo-chosei-josei-kin-seido) had an economically significant impact on preserving jobs during the crisis. OECD (2010) further suggests that, apart from short-time working, reductions in overtime and employer-initiated reductions in working time also accounted for a substantial part of the overall reduction in working time. The exceptional role of working-time adjustments during the most recent crisis, however, is at odds with the increased incidence of non-standard work and the increased scope for employers to make adjustments on the employment margin.

In order to shed further light on the aggregate labour market dynamics that are observed during the recent crisis, micro-economic data are necessary to examine how the adjustment behaviour of firms has changed during the past two decades, while controlling for any differences in the business environment across firms and over time. It is important to control for differences in shocks across firms because the adjustment technologies of firms differ across different types of firms. Gal et al. (2012) document large differences in terms of the sensitivity of labour inputs to output shocks across industries and firm-size groups. This implies that the way output shocks are distributed across different types of firms can have 
important implications for aggregate labour market dynamics. ${ }^{10}$ Moreover, it is also important to account for non-linearities in the relationship between employment, or its flow components (hires and separations), and output shocks as emphasised by Caballero et al. (1997) and Davis et al. (2006, 2011). ${ }^{11}$

\section{Methodology}

The methodological framework in this paper builds on previous work by Gal et al. (2012) by allowing for different adjustment technologies between different types of firms as well as by Davis et al. (2006, 2011) by allowing for non-linearities in the labour input adjustment technologies with respect to the size of output shocks. The main novelties of the present approach are that it differentiates between standard and non-standard workers and takes account of both changes in employment and changes in working time.

\subsection{Decomposing labour-input adjustment}

Shocks are characterised by means of changes in total hours worked at the establishment level. The advantage of focusing on total hours worked instead of employment as in previous studies that use a similar approach (Davis et al., 2006; Bellman et al., 2011; Davis et al., 2011) is that it also allows accounting for average hours changes which is particularly important in Japan. Shocks cannot be characterised in terms of sales as the data used for this paper lack this information. This means that the present analysis does not consider the role of labour hoarding during the crisis in the form of reduced hourly labour productivity.

In order to analyse the way the firms adjust to shocks, it is useful to start by decomposing total hours worked (L) as follows:

$$
L=N Q
$$

10 . In an early paper, Davis and Haltiwanger (1989), also emphasise the role of heterogeneity between sectors and/or idiosyncratic factors for aggregate labour market dynamics.

11. Davis et al. (2006, 2011) empirically analyse the relationship between worker and job flows in the crosssection and over time. Their main findings are that the relationship between hires and layoffs, on the one hand, and net employment changes, on the other, is highly non-linear in the cross-section; that these relationships are stable over time; and that, as a result, shifts in the cross-sectional distribution of employment growth allow one to explain aggregate hiring and firing dynamics pretty well. This is in line with the tight link between job and worker flows implied by standard search models of the labour market. However, these same models do not appear to explain aggregate variations in quits very well, suggesting that the relationship between quits and employment changes depends on the business cycle. 
where $N$ refers to employment and $Q$ to average hours worked. Totally differentiating (1) and multiplying both sides by $\frac{L}{\bar{L}}$ yields the growth rate of total hours:

$$
\frac{\Delta L}{\bar{L}}=\frac{\Delta N}{\bar{L}} \frac{L}{N}+\frac{\Delta Q}{\bar{L}} \frac{L}{Q}
$$

Bars refer to the average between the current and previous period. Including the distinction between hires and separations, equation (2) can be rewritten as:

$$
\Delta l=Q(h-s)+N \Delta q
$$

where $\Delta l$ refers to the growth rate in total hours, $h$ to the hiring rate, $s$ to the separation rate and $\Delta q$ to the growth rate in average hours worked $\left(\frac{\Delta L}{\bar{L}}=\Delta l ; \frac{\Delta N}{\bar{L}}=h-s, \Delta q=\frac{\Delta Q}{\bar{L}}\right)$. The empirical analysis examines the role of labour demand shocks, defined in terms of total hours worked, for changes in $h$, $s$, and $\Delta q$.

\subsection{Analysing the micro-economic behaviour of establishments in response to shocks}

In order to analyse the role of labour-demand shocks for labour-input adjustment, one may proceed either non-parametrically or parametrically. Both methods will be used in this paper. ${ }^{12}$ The two methods are applied to the entire of sample of establishments as well as separately for clusters of establishments which are likely to share a common adjustment technology. Clusters may refer to, for example, different sectors or firm-size groups.

The non-parametric method to analysing the relationship between labour-input adjustment and changes in total hours worked is implemented by dividing the distribution of the growth rate of total hours in narrow growth intervals, $g$, and documenting the average values of labour-input adjustment within each bin. More specifically, the adjustment behaviour of establishments in terms of $x$ - which may stand for $h, s$ or $\Delta q$ - with respect to total hours worked is analysed as follows:

$$
x_{i t}=\alpha_{i}+\sum_{g} \beta^{g} D_{i t}^{g}+\varepsilon_{i t}
$$

12. The advantage of non-parametric methods is that it avoids having to make assumptions about the functional form of labour input adjustment with respect to shocks. This is particularly important when the relationship between labour input changes and shocks is non-linear. The advantage of parametric methods is mainly that it allows for a more parsimonious representation. 
where $\alpha_{i}$ refers to an establishment fixed effect, $\beta^{g}$ relates the within-establishment variation in $x_{i t}$ to being in growth interval $g, D_{i t}^{g}$ to a set of growth interval dummies ("bin dummies") and $\varepsilon_{i t}$ to a random error term. The empirical model is identical to that used by Davis et al. (2006, 2011) except that the analysis here conditions on the growth rate of total hours instead of that of employment. ${ }^{13}$

The parametric method involves assuming that labour input adjustment is linear in the growth rate of total hours over the entire negative domain and the entire positive domain (Bellman et al., 2011). Thus, one may represent labour-input adjustment in response to the growth rate of total hours worked as follows:

$$
x_{i t}=\alpha_{i}+\beta^{n} \Delta l_{i t} I\left(\Delta l_{i t}<0\right)+\beta^{p} \Delta l_{i t} I\left(\Delta l_{i t}>0\right)+\varepsilon_{i t}
$$

where $I($.$) is an indicator function that takes the value of one if the expression in brackets is true and$ zero otherwise. $\beta^{n}$ measures the responsiveness of factor $x$ with respect to negative values in the growth rate of total hours, that is, in shrinking establishments, whereas $\beta^{p}$ measures the responsiveness of factor $x$ with respect to positive values in the growth rate of total hours, that is, in expanding establishments.

In addition to estimating (4.1) and (4.2) for all workers, the models are estimated separately for $h^{\text {sw }}$, $s^{s w}$ or $\Delta q^{s w}$ and $h^{n s w}$, $s^{n s w}$ or $\Delta q^{n s w}$ and each year, with superscripts $s w$ and $n s w$ referring to standard and non-standard workers respectively. These estimates will also be used as inputs for the simulation analysis (see Section 3.3).

\subsection{Explaining aggregate dynamics during the recent crisis using simulation methods}

Aggregate labour market dynamics can be analysed by combining the non-parametric estimates discussed above with information on the shock distribution as follows.

First, to allow for heterogeneity in the adjustment technology across establishments, workers and over time, we estimate (4.1) separately for each cluster $j$ (combination of industry, establishment size, employment status) and crisis period $p$ (1997 crisis: 1997Q2-1998Q2 and global financial crisis: 2008Q42009Q4). This yields a set of technology coefficients $\beta_{j p}^{g}$ for each bin and cluster to describe the average hiring and separation technology during each crisis period.

Second, using the heterogeneous technology coefficients with their corresponding weights allows generating the aggregate dynamics in hires and separations as follows:

$13 \quad$ As discussed by Davis et al. (2006, 2011), since the changes in total hours or employment are not perfectly determined before hires and separations, equation (4.1) should be interpreted as a statistical decomposition. 
(5) $\hat{X}_{t}=\sum_{\mathrm{g}} \sum_{j} \omega_{j t}\left(\sum_{i} w_{i j t} \hat{x}_{i j t}\right)=\sum_{j} \omega_{j t} \sum_{g} \sum_{i} w_{i j t} D_{i t}^{g} \hat{\beta}_{j p}^{g}$

where $\hat{x}_{i j t}$ corresponds to the predicted hiring rate, separation rate or employment growth in establishment $\mathrm{i}$ at time $t, \omega_{j t}$ to the employment share of group $j$ in total employment at time period $t$ and $w_{i j t}$ the employment share of establishment $i$ in employment of group $j$ at time $t$ (sampling weight normalised by group employment). The expression following the second equality shows that aggregate labour market dynamics depend on a composition effect $\left(\omega_{j t}\right)$, a shock effect $\left(\sum_{i} w_{i j t} D_{i t}^{g}\right)$ and a technology effect $\left(\sum_{g} \hat{\beta}_{j p}^{g}\right)$.

The final step for explaining differences in aggregate labour market dynamics between the 1997 crisis and the global financial crisis is to calculate the contribution of each component (composition, shock and technology) for the cumulative growth rates in hires, separations and employment. The difference in cumulative growth rates that can be attributed to, respectively, the technology $\operatorname{effect}\left(\Delta \mathrm{X}_{\text {tech }}\right)$, the composition effect $\left(\Delta \mathrm{X}_{\text {comp }}\right)$ and the shock effect $\left(\Delta \mathrm{X}_{\text {shock }}\right)$ is given by:

$$
\Delta \mathrm{X}_{\mathrm{tech}}=\sum_{t \in\{2008 Q 4,2009 Q 4\}} \sum_{\mathrm{g}} \sum_{\mathrm{j}} \omega_{j t}\left(\sum_{i} w_{i j t} D_{i t}^{g}\right)\left(\hat{\beta}_{j 2008}^{g}-\hat{\beta}_{j 1997}^{g}\right)
$$

$$
\Delta \mathrm{X}_{\mathrm{comp}}=\sum_{t \in\{2008 Q 4,2009 Q 4\}} \sum_{\mathrm{g}} \sum_{\mathrm{j}}\left(\omega_{j t}-\omega_{j 1997}\right)\left(\sum_{i} w_{i j t} D_{i t}^{g}\right) \hat{\beta}_{j 1997}^{g}
$$

$$
\Delta \mathrm{X}_{\text {shock }}=\sum_{t \in\{2008 Q 4,2009 Q 4\}} \sum_{\mathrm{g}} \sum_{\mathrm{j}} \omega_{j 1997}\left(\sum_{i} w_{i j t} D_{i t}^{g}-w_{j 1997} D_{1997}^{g}\right) \hat{\beta}_{j 1997}^{g}
$$

where 1997 subscripts reflect the average values during the 1997 crisis.

The technology effect is given by the difference in outcomes that is obtained when comparing the cumulative outcome for the global financial crisis based on equation (5) with the counterfactual outcome that would have occurred had the technology coefficients remained at their values during the 1997 crisis. Both the actual and the counterfactual outcomes are evaluated using the composition of establishments and workers and the distribution of shocks during the global financial crisis. Given the technology effect, the composition effect is given by the difference in outcomes that is obtained when comparing the alternative 
outcomes that was used to calculate the technology effect with the counterfactual outcome that would have occurred if the composition of establishments and workers remained as observed during the 1997 crisis. The shock effects is given by the differences in outcomes that is obtained when comparing the alternative outcome that was used to calculate the composition effect and the counterfactual outcome that would have occurred if the shocks density had been as during the 1997 crisis. . ${ }^{14}$

\section{Data}

The analysis makes use of two different comprehensive and nationally representative datasets of establishments for the period 1991-2009: the Monthly Labour Survey (hereafter, MLS) and Employment Trend Survey (hereafter, ETS). MLS is a monthly establishment survey, similar to JOLTS in the US, that provides information on employment, gross hires and separations, total hours (and standard and overtime separately), the total wage bill (and, separately, standard, overtime and bonus payments). It does not include details on the reason of separations. ETS is a six-monthly survey of employment, hires and separations, including layoffs and quits. ${ }^{15}$

\subsection{Monthly Labour Survey}

The data of MLS can be broken down by gender or workplace title (standard/non-standard). The raw data contains on average 33,000 establishment observations each month. The survey covers establishments with five employees or more in all market sectors except agriculture and fisheries. The monthly data are transformed into quarterly ones to make the dataset more manageable. The final dataset consists of 1,526,067 establishment-quarter observations.

The sampling of the Monthly Labour Survey is relatively complex due to the role of rotation. The sample consists for $50 \%$ of establishments with 30 or more employees and for $50 \%$ of establishments with less than 30 employees. For establishments with more than 30 employees, a completely new sample is used every two or three years (referred to as "major" rotation). This new sample is followed every month until a completely new sample is selected. Establishments that leave the sample during the period are replaced by new ones from the sampling frame. For establishments with less than 30 employees, the sample rotates every six months so that one third of establishments below 30 employees leaves the sample, two thirds continue and one third enters (this represents a "minor" rotation). This implies that such establishments are

14 While the decompositions are neutral to its order thanks to the linear additivity, as in the Oaxaca-Blinder decomposition, the base year may affect the magnitude of decomposition.

15. The surveys do not allow one to consider the role of entry and exit. 
followed for a period of 18 months until they rotate out of the sample. New establishments are selected using stratified random sampling by industry and establishment size. All relevant data series are adjusted to account for seasonal fluctuations and fluctuations related to major rotations in the sample. ${ }^{16}$

Table 1 presents some descriptive statistics based on the MLS by total hours-growth category. It shows that stable establishments, defined here as establishments with absolute growth rates of less than $2.5 \%$, account for about $20 \%$ of all observations; establishments with absolute growth rates between 2.5 and $10 \%$ account for about $45 \%$ of all observations; establishments with absolute growth rates between 10 and $20 \%$ account for over $20 \%$; and establishments with absolute growth rates larger than $20 \%$ (excluding entry and exit) account for about $12 \%$. Thus, about two-thirds of the sample consists of establishments with absolute growth rates equal or smaller than $10 \%$.

The establishment-growth distribution differs importantly across firm-size categories, with small firms being more likely to exhibit large absolute growth rates. However, it is relatively stable across industry sectors, except construction where relatively large growth rates are more common. Interestingly, establishments with large absolute growth rates tend to make more intensive use of non-standard workers. This may either reflect the possibility that establishments operating in more volatile markets choose to make more intensive use of non-standard workers or that establishments with higher shares of nonstandard workers adjust more quickly in response to shocks.

There appears to be a positive relationship between, on the one hand, average hours worked and the use of overtime, and, on the other, the total hours change (workers in expanding firms work more). The relationship between hours worked/overtime and total hours growth is similar for standard workers and non-standard workers. However, non-standard workers work considerably less on average hours than standard workers, reflecting the high incidence of part-time workers in the group of non-standard workers. Non-standard workers nevertheless tend to account for a disproportionate share of overtime hours (their share of overtime is larger than their share in employment).

Average hourly wages are largest in relatively stable establishments. In part, this reflects a composition effect, since large firms tend to be more stable and pay higher wages. However, it may also reflect the possibility that offering higher wages helps maintaining stable employment levels. The positive

16 The adjustment procedure involves the following steps. First, teach variable is regressed on four quarter dummies or two major rotation point dummies without a constant; then, the predicted value $\hat{y}_{1}$ or $\hat{y}_{2}$ is retrieved, respectively. Each variable is then adjusted by subtracting from each observation the adjustment term $\hat{\mathrm{y}}_{1}-\hat{\mathrm{y}}_{2}$. 
relationship between hourly wages and absolute hourly growth rates is primarily driven by standard workers, while there is no apparent relationship for non-standard workers.

Table 1. Summary statistics ${ }^{1)}$ based on total hour change quarterly MLS; 1992 Q1 to 2009 Q4

\begin{tabular}{|c|c|c|c|c|c|c|c|c|}
\hline & \multirow[b]{2}{*}{ total } & \multicolumn{7}{|c|}{ Total Hour Change } \\
\hline & & $<-0.2$ & $\begin{array}{c}-0.2>=\&- \\
0.1\end{array}$ & $\begin{array}{c}-0.1\rangle=\&- \\
0.025<=\end{array}$ & $\begin{array}{c}-0.025\rangle=\& \\
-0.025<=\end{array}$ & $\begin{array}{c}0.025>\& \\
0.1<=\end{array}$ & $\begin{array}{c}0.1>\& \\
0.2<=\end{array}$ & $0.2>$ \\
\hline \multicolumn{9}{|l|}{ number of observation } \\
\hline & 1526067 & 90794 & 177615 & 366122 & 305962 & 328195 & 172765 & 84598 \\
\hline \multicolumn{9}{|l|}{ mean of employment characteristics } \\
\hline average employment & 182.3 & 87.8 & 162.2 & 213.4 & 211.7 & 188.9 & 158.9 & 108.0 \\
\hline share of non-standard workers (\# of employment) & 0.183 & 0.227 & 0.183 & 0.168 & 0.173 & 0.182 & 0.186 & 0.239 \\
\hline \multicolumn{9}{|l|}{ mean of hour worked characteristics } \\
\hline average hour worked & 160.6 & 141.8 & 152.5 & 157.9 & 161.4 & 165.6 & 169.4 & 169.4 \\
\hline average hour worked (standard workers) & 174.1 & 157.7 & 165.5 & 169.9 & 173.7 & 179.1 & 183.9 & 189.4 \\
\hline average hour worked (non-standard workers) & 105.9 & 92.4 & 101.0 & 104.3 & 106.1 & 108.9 & 111.8 & 112.3 \\
\hline share of overtime & 0.052 & 0.039 & 0.048 & 0.051 & 0.052 & 0.055 & 0.057 & 0.059 \\
\hline share of overtime (standard workers) & 0.057 & 0.044 & 0.052 & 0.055 & 0.056 & 0.059 & 0.063 & 0.066 \\
\hline share of overtime (non-standard workers) & 0.016 & 0.013 & 0.015 & 0.016 & 0.016 & 0.017 & 0.018 & 0.022 \\
\hline share of non-standard workers (total hour) & 0.142 & 0.178 & 0.142 & 0.130 & 0.133 & 0.142 & 0.143 & 0.187 \\
\hline \multicolumn{9}{|l|}{ mean of wage characteristics } \\
\hline average log of hourly wage & 3.49 & 2.88 & 3.45 & 3.77 & 3.65 & 3.35 & 3.33 & 3.33 \\
\hline average log of hourly wage (standard workers) & 3.79 & 3.24 & 3.75 & 4.07 & 3.95 & 3.62 & 3.61 & 3.71 \\
\hline average log of hourly wage (non-standard workers) & 1.24 & 1.27 & 1.19 & 1.25 & 1.25 & 1.22 & 1.22 & 1.36 \\
\hline \multicolumn{9}{|l|}{ industry shares } \\
\hline manufacturing & 0.33 & 0.34 & 0.35 & 0.33 & 0.32 & 0.33 & 0.34 & 0.32 \\
\hline construction & 0.07 & 0.12 & 0.07 & 0.06 & 0.06 & 0.06 & 0.07 & 0.11 \\
\hline retail, wholesale, restaurant & 0.18 & 0.17 & 0.18 & 0.18 & 0.18 & 0.19 & 0.18 & 0.18 \\
\hline other service & 0.29 & 0.27 & 0.28 & 0.30 & 0.30 & 0.28 & 0.29 & 0.29 \\
\hline others & 0.13 & 0.09 & 0.12 & 0.13 & 0.13 & 0.13 & 0.12 & 0.11 \\
\hline \multicolumn{9}{|l|}{ firm size shares } \\
\hline over 100 & 0.40 & 0.29 & 0.39 & 0.43 & 0.43 & 0.41 & 0.39 & 0.30 \\
\hline $30-99$ & 0.11 & 0.11 & 0.12 & 0.11 & 0.11 & 0.12 & 0.12 & 0.11 \\
\hline under 30 & 0.43 & 0.57 & 0.44 & 0.39 & 0.40 & 0.41 & 0.44 & 0.55 \\
\hline
\end{tabular}

Source: Author's calculations based on Monthly Labor Survey.

1) Unweighted mean across establishments.

Table 2 provides some details on the use of non-standard workers by industry, firm size and selected years. It confirms that the share of non-standard workers in employment and total hours worked has increased gradually over time, increasing from $14 \%$ (11\%) in terms of employment (total hours worked) to 22\% (17\%) in 2006 and 23\% (18\%) in 2009. Moreover, average hours worked declined by a proportionally larger amount among non-standard workers than standard workers during the crisis. This provides a first indication that the role of non-standard work in Japan deviates from the standard view that non-standard workers provide more flexibility to firms in terms of employment and, as a result, reduces the importance of average hours worked as a margin of adjustment.

The importance of non-standard work varies importantly across industries and firm-size groups. The incidence of non-standard work decreases with firm size: it ranges from 15\% (11\%) in terms of employment (total hours worked) in firms with more than 100 employees to $22 \%$ (17\%) in firms with less than 30 employees. The retail, wholesale and restaurants sector has the highest incidence of non-standard work: $35 \%$ (29\%) in terms of employment (total hours worked), while it is lowest in the construction sector (5 and $3 \%$ respectively). 
Table 2. Utilization of non-standard workers ${ }^{11}$ by industry, firm size, and selected years quarterly MLS

\begin{tabular}{|c|c|c|c|c|c|c|c|c|}
\hline & \multicolumn{2}{|c|}{$\begin{array}{c}\text { share of non-standard } \\
\text { worker }\end{array}$} & \multicolumn{2}{|c|}{ average hour worked } & \multicolumn{2}{|c|}{ share of overtime } & \multicolumn{2}{|c|}{$\begin{array}{l}\text { average log of hourly } \\
\text { wage }\end{array}$} \\
\hline & $\begin{array}{c}\# \text { of } \\
\text { employmen } \\
t\end{array}$ & total hour & standard & $\begin{array}{c}\text { non } \\
\text { standard }\end{array}$ & standard & $\begin{array}{c}\text { non } \\
\text { standard }\end{array}$ & standard & $\begin{array}{c}\text { non } \\
\text { standard }\end{array}$ \\
\hline \multicolumn{9}{|l|}{ industry } \\
\hline manufacturing & 0.142 & 0.114 & 175.5 & 117.8 & 0.069 & 0.019 & 3.36 & 1.14 \\
\hline construction & 0.051 & 0.033 & 176.8 & 104.2 & 0.045 & 0.011 & 2.88 & 1.14 \\
\hline retail, wholesale, restaurant & 0.354 & 0.290 & 182.1 & 102.5 & 0.042 & 0.013 & 2.98 & 1.00 \\
\hline other service & 0.194 & 0.140 & 168.6 & 95.7 & 0.047 & 0.015 & 4.39 & 1.51 \\
\hline others & 0.087 & 0.063 & 170.3 & 106.5 & 0.072 & 0.022 & 5.15 & 1.24 \\
\hline \multicolumn{9}{|l|}{ firm size } \\
\hline over 100 & 0.145 & 0.114 & 168.4 & 109.2 & 0.069 & 0.022 & 5.19 & 1.39 \\
\hline $30-99$ & 0.175 & 0.135 & 178.3 & 109.5 & 0.059 & 0.015 & 3.24 & 1.11 \\
\hline under 30 & 0.222 & 0.171 & 179.0 & 101.5 & 0.040 & 0.010 & 2.38 & 1.06 \\
\hline \multicolumn{9}{|l|}{ selected year } \\
\hline 1994 & 0.140 & 0.106 & 175.6 & 108.9 & 0.053 & 0.013 & 3.92 & 1.23 \\
\hline 1997 & 0.153 & 0.116 & 173.3 & 106.5 & 0.058 & 0.014 & 4.11 & 1.23 \\
\hline 2000 & 0.174 & 0.135 & 174.7 & 107.9 & 0.057 & 0.016 & 3.94 & 1.23 \\
\hline 2003 & 0.194 & 0.150 & 173.1 & 105.5 & 0.059 & 0.018 & 3.82 & 1.26 \\
\hline 2006 & 0.215 & 0.170 & 176.1 & 106.2 & 0.064 & 0.020 & 3.75 & 1.26 \\
\hline 2009 & 0.234 & 0.184 & 170.3 & 100.0 & 0.054 & 0.018 & 3.72 & 1.28 \\
\hline
\end{tabular}

Source: Author's calculations based on Monthly Labour Survey.

1) Unweighted mean across establishments.

\subsection{Employment Trend Survey}

The ETS samples about 10,000 establishments every year with less than 500 employees and includes all establishments with more than 500 employees. ${ }^{17}$ Once sampled, establishments report, twice a year, the level of employment and the number of worker flows. Apart from very large firms, this implies that the ETS essentially represents a cross-section. Similar to the MLS, it covers establishments with more than 5 employees in all industries except agriculture and fisheries.

The ETS provides information on hires and separations, in the case of the latter, the reason. The reason of separation is used to define layoffs and quits. Layoffs are defined as separations due to the expiration of a temporary contract, dismissal, and mandatory retirement due to age. ${ }^{18}$ Quits are defined as separations for personal reasons. ${ }^{19}$ In addition to quits and layoffs, the survey also identifies a third category of separations, namely, transfers. This refers to worker transitions between establishments of the same firm.

17. Firms with less than 500 employees are selected using random-stratified sampling with the strata being prefecture, industry and establishment-size group.

18. In the case of mandatory retirement, employers usually have the possibility to retain the workers by offering retirees short-term fixed-term contracts.

19. The detailed categories of 'Personal reasons' has been changed from time to time, adding the new categories such as 'Marriage,' 'Maternity/child care,' 'Long-term care,' and 'Other personal reasons.' 
Table 3 presents descriptive statistics by employment-growth category. It shows that relative to the hours-growth distribution (cf. Table 1), the employment-growth distribution is less dispersed. This may reflect to importance of adjustment costs in relation to employment changes relative to changes in average hours worked. Establishments with absolute employment growth rates of $2.5 \%$ or less account for over $35 \%$ of all observations, establishments with absolute employment growth rates between 2.5 and $10 \%$ account for about $40 \%$, while establishments with absolute employment growth rates larger than $10 \%$ account for just $25 \%$.

The share of non-standard workers in employment is $6.6 \%$ in the ETS, considerably less than in the MLS, despite using the same definition of non-standard work in the two surveys. This reflects the fact that the descriptive statistics discussed in this section are based on the raw data and do not take account of the sampling weights. Given the large differences in the sampling design of the two structures this can lead to large differences in the composition of the respective samples. Since the ETS places a much larger weight on large firms which tend to be characterised by lower incidence of non-standard work it is not surprising that the average incidence of non-standard work is considerably lower. When comparing the incidence of temporary work within firm-size cells or when applying the sampling weights these differences become are largely disappear.

Table 3. Summary statistics ${ }^{1)}$ for each bin based on employment size change yearly ETS; 1991 to 2009

\begin{tabular}{|c|c|c|c|c|c|c|c|c|}
\hline & \multirow[b]{2}{*}{ total } & \multicolumn{7}{|c|}{ Employment Change } \\
\hline & & $<-0.2$ & $\begin{array}{c}-0.2>=\&- \\
0.1\end{array}$ & $\begin{array}{c}-0.1>=\&- \\
0.025<=\end{array}$ & $\mid \begin{array}{c}-0.025>=\& \\
-0.025<=\end{array}$ & $\begin{array}{c}0.025>=\& \\
0.1<=\end{array}$ & $\begin{array}{c}0.1>\& \\
0.2<=\end{array}$ & $0.2>$ \\
\hline \multicolumn{9}{|l|}{ Number of observation } \\
\hline & 165904 & 9341 & 14655 & 36530 & 60371 & 28848 & 10883 & 5276 \\
\hline \multicolumn{9}{|l|}{ Mean of employment characteristics } \\
\hline average employment & 382.01 & 202.69 & 248.94 & 450.33 & 418.82 & 439.46 & 220.45 & 193.96 \\
\hline share of non-standard workers & 0.066 & 0.064 & 0.083 & 0.061 & 0.058 & 0.077 & 0.083 & 0.098 \\
\hline \multicolumn{9}{|l|}{ Industry Shares } \\
\hline manufacturing & 0.52 & 0.53 & 0.54 & 0.59 & 0.52 & 0.49 & 0.44 & 0.43 \\
\hline construction & 0.06 & 0.07 & 0.06 & 0.05 & 0.05 & 0.07 & 0.08 & 0.09 \\
\hline retail, wholesale, restaurant & 0.08 & 0.08 & 0.09 & 0.08 & 0.08 & 0.06 & 0.08 & 0.09 \\
\hline other service & 0.21 & 0.18 & 0.18 & 0.15 & 0.22 & 0.24 & 0.26 & 0.25 \\
\hline others & 0.13 & 0.14 & 0.13 & 0.13 & 0.13 & 0.14 & 0.13 & 0.14 \\
\hline \multicolumn{9}{|l|}{ firm size shares } \\
\hline over 100 & 0.20 & 0.29 & 0.27 & 0.09 & 0.23 & 0.11 & 0.31 & 0.35 \\
\hline $30-99$ & 0.17 & 0.19 & 0.20 & 0.19 & 0.14 & 0.20 & 0.21 & 0.18 \\
\hline under 30 & 0.63 & 0.52 & 0.53 & 0.72 & 0.63 & 0.69 & 0.48 & 0.47 \\
\hline
\end{tabular}

Source: Author's calculations based on Employment Trend Survey

1) Unweighted mean per one establishment.

\section{Micro-economic analysis of labour input adjustment}

This section presents results on, respectively: i) the aggregate relationship between labour input adjustment and labour demand shocks; ii) the role of non-standard work; and iii) the role of industry and firm size. 


\subsection{Baseline analysis of labour input adjustment}

\section{Employment change}

Figure 5 presents non-parametric evidence on the relationship between worker flows and employment changes for absolute changes smaller than $20 \% .{ }^{20}$ Panel A represents the decomposition of employment growth into hires and separations, while panel B decomposes separations into layoffs, quits and transfers.

The relationship between worker and jobs flows is highly non-linear. The kinks in the hiring and separations functions in Panel A reflect the difficulty of reducing employment through a reduction in the hiring rate relative to an increase in the separation rate and the difficulty of increasing employment through a reduction in the separation rate relative to an increase in the hiring rate. However, within the negative or positive domains, the hiring or the separation curves in Panel A appear broadly linear. The approximately linear relationship between job and workers flows on the positive and negative domains suggests that a parametric approach that imposes linearity, but allows the slope coefficients to differ between the negative and the positive domain, describes the relationship between worker and job flows reasonably well.

We now discuss the relationship between job and worker flows in more detail by focusing on the degree of worker turnover in stable establishments and the role of hires (separations) in declining (expanding) firms. ${ }^{21}$ Panel A shows that the annual hiring and separation rates in stable establishments are slightly above $10 \%$. This implies that the annual rate of worker movements, the churning rate, is somewhat above 20\%. Panel B shows that quits and transfers account for the bulk of separations among stable establishments, with quits accounting for about half the number of separations and transfers for a third. The increase in the separation rate on the positive domain appears to be driven by quits, and to a lesser extent, transfers. ${ }^{22}$ The layoff rate does not vary over the positive domain. On the negative domain, the relative importance of transfers and, to a lesser extent, layoffs increases the larger the reduction in employment, while the role of quits decreases with the reduction of employment.

20. We do not control, here, without establishment fixed effects since the ETS is cross-section dataset.

21. Since the difference between the hiring and separation rates yields the employment growth by construction, it is sufficient to discuss just one of these relationships.

22. An upward-sloping separation function in the positive domain has also been found in Teruyama and Genda (2009). 
Figure 5. The relationship between worker flow rates and employment growth rates
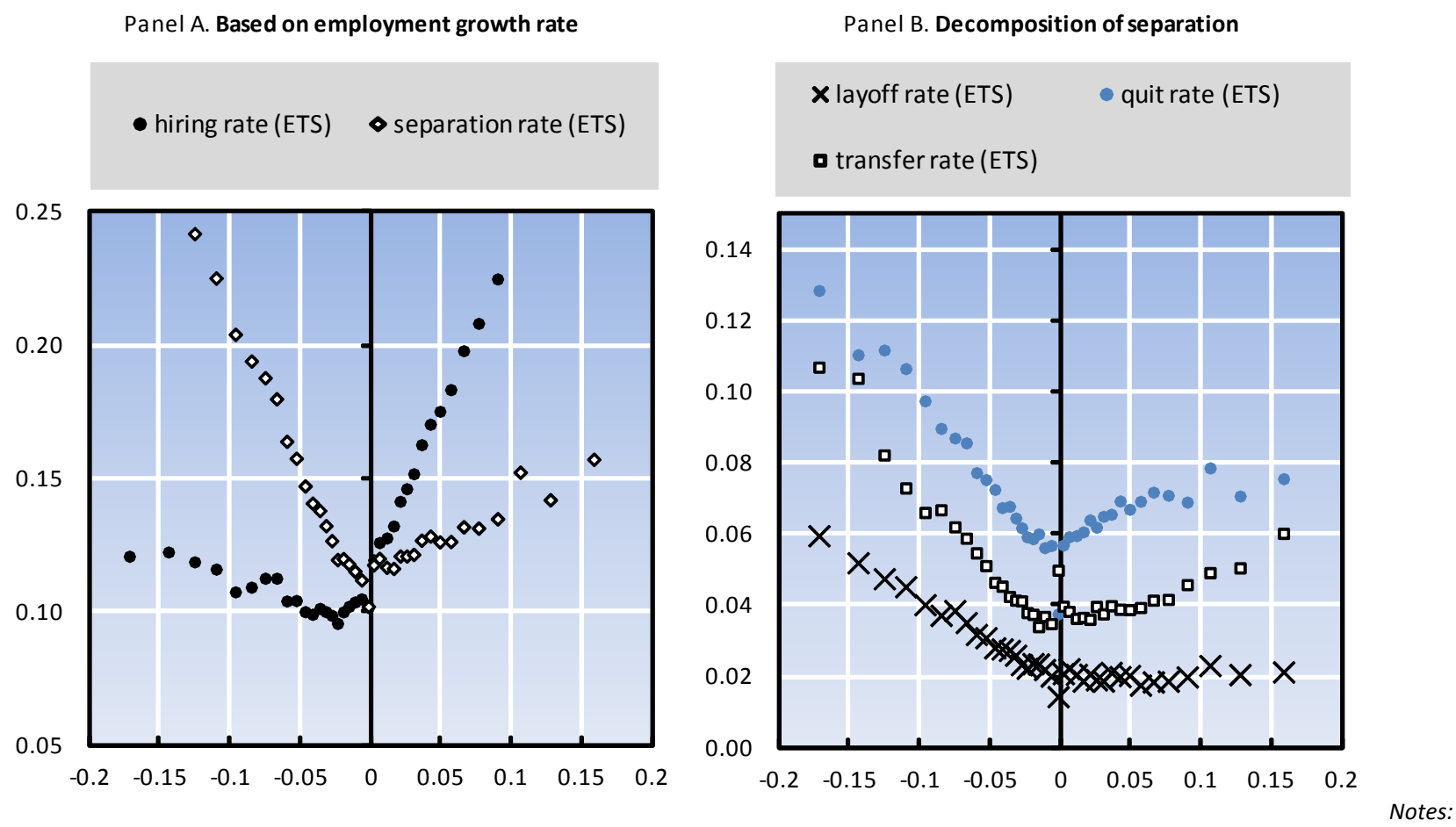

Estimates based on weighted OLS.

Source: Authors' calculations based on annualized Employment Trend Survey (ETS)

The exercise in Figure 5 is similar to that presented in Davis et al. (2006). They also document a kink around zero employment change. The relative importance of worker flows is not directly comparable since the figures in Davis et al. (2006) are based on monthly changes instead of yearly flows as in the present case. However, multiplying the monthly rates in Davis et al (2006) times twelve suggests that worker turnover is about as important in Japan as it is in the United States. The main difference may be that declining establishments in Japan are more likely to rely on attrition than on layoffs. This may indicate that layoffs are more costly in Japan.

\section{Total hour change}

Figure 6 presents non-parametric evidence on the relationship between the hiring rate, the separation rate, the growth rate in average hours, on the one hand, and the growth rate of total hours worked, on the other.

Compared with Figure 5, the hiring and separation functions with respect to the growth rate of total hours in Figure 6 are smoother. While the hiring rate (separation rate) increases (decreases) much more strongly on the positive (negative) domain than on the negative (positive) domain, there is no longer a clear 
indication of a kink at zero. The smooth but still highly non-linear hiring and separation functions suggest that parametric estimates of the relationship between workers flows and total hours changes may not be as appropriate as in the case of employment changes.

The figure further points to the presence of a S-shaped relationship between the growth rate of total hours worked and that of average hours worked, i.e. average hours adjustment is relatively more important for small changes than for large changes in total hours. Changes in average hours growth are effectively zero on average for establishments in which total hours worked are constant. For growth rates of total hours worked close to zero, the growth rate in the average hours rate accounts for almost the entire change. Average hours changes account for about 99\% (80\%) of the reduction in total hours worked in establishments reducing total hours worked by 1\% (5\%). For changes in total hours worked of 50\% (not shown), adjustments in average hours worked account for slightly more than half the change in total hours. The considerable importance of average hours changes, even in establishments experiencing very large changes in total hours is likely to be a specificity of the Japanese labour market, ${ }^{23}$ but the non-linear relationship between total and average hours is likely to be present in most other countries. Indeed, a somewhat similar S-shaped relationship has also been documented for the United States in Caballero et al. (1997).

The non-linear relationship between total hours changes and changes in average working hours implies that aggregate shocks that are approximately evenly distributed across establishments tend to be accounted for to a greater important extent by average hours adjustments than shocks that affect certain establishments more than others. This highlights the importance of accounting for the distribution of shocks in addition to its mean level when trying to explain cross-country patterns in labour market adjustment.

23. Macro-level statistics certainly suggest this is the case. See, for example, OECD (2010). 
Figure 6. The relationship between labour-input adjustment and the total hour growth rate

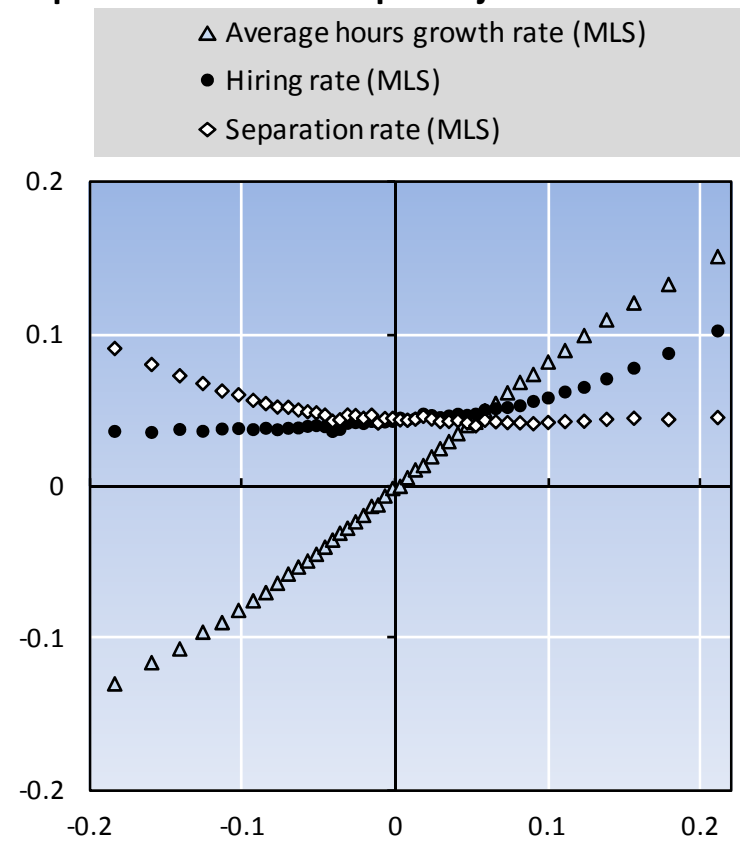

Source: Authors' calculations based on Monthly Labour Survey (MLS)

\subsection{The role of non-standard work for labour input adjustment}

Figure 7 documents the relationship between changes in total hours worked with employment changes, hiring rates and separation rates for standard and non-standard workers. ${ }^{24}$ Non-standard worker employment is more sensitive to change in total hours worked than standard worker employment (Panel A). Of course, this also implies that working time of non-standard workers is less sensitive to total hours changes than working time of standard workers. This suggests that the burden of employment adjustment tends to be concentrated on non-standard workers. Churning is about twice as high among non-standard workers than among standard workers (Panel B and C). The intercepts of the hiring and separations curve for standard workers range from 2 to $3 \%$, while they range from 5 to $6 \%$ for non-standard workers. 
Figure 7. The relationship between labour-input adjustment and the total hour growth rate
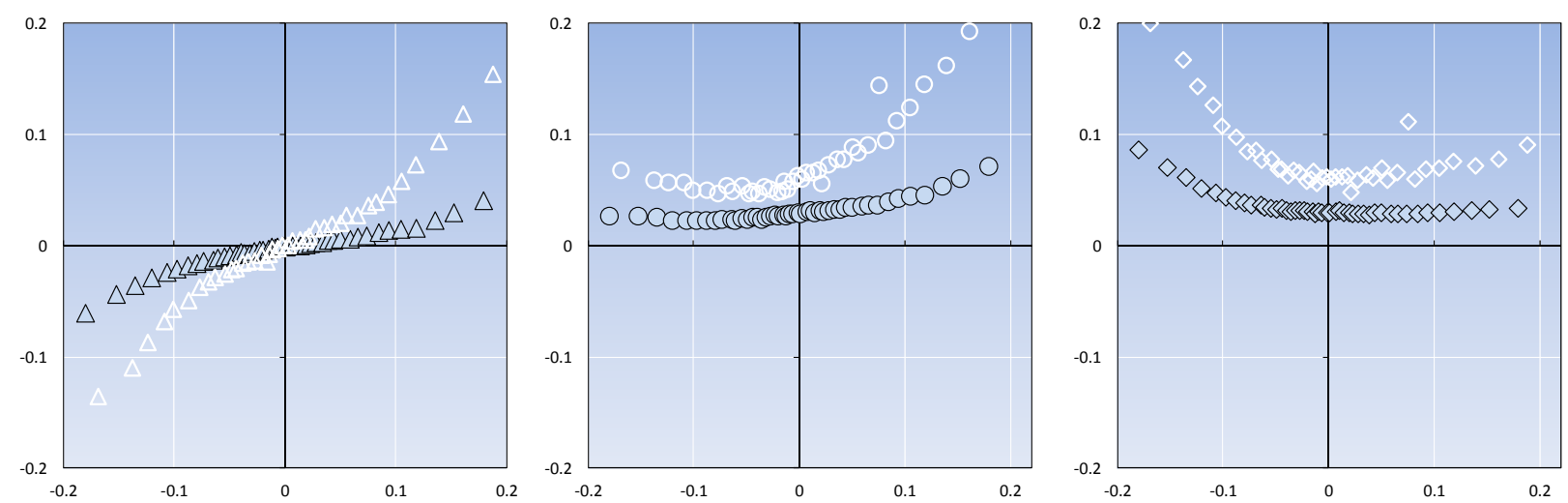

Source: Authors' calculations based on Monthly Labour Survey, Based on weighted OLS model

\subsection{Labour input adjustment by size, industry and time period}

The adjustment behaviour of total hours also differs across establishments of different sizes or in different industries. In the interest of space, the discussion concentrates on the parametric estimates which are reported in Table 4.

Table 4. Aggregate parametric results by firm size, industry and employment status (total hour change) Restricted sample (-10\% to $+10 \%$ change)

\begin{tabular}{|c|c|c|c|c|c|c|c|c|c|c|c|c|c|c|c|}
\hline & \multirow{2}{*}{\multicolumn{5}{|c|}{ Hiring Rates }} & \multirow{2}{*}{\multicolumn{5}{|c|}{ Separation Rates }} & \multirow{2}{*}{\multicolumn{5}{|c|}{ Avrage Hour Changes }} \\
\hline & & & & & & & & & & & & & & & \\
\hline & \begin{tabular}{|c|} 
Positive \\
regime $\left(\beta^{p}\right)$
\end{tabular} & $\begin{array}{l}\text { Negative } \\
\text { regime }\left(\beta^{n}\right)\end{array}$ & Constant & \# of obs. & $\mathrm{R}^{2}$ & $\begin{array}{l}\text { Positive } \\
\text { regime }\left(\beta^{p}\right)\end{array}$ & $\begin{array}{c}\text { Negative } \\
\text { regime }\left(\beta^{n}\right) \\
\end{array}$ & Constant & \# of obs. & $\mathrm{R}^{2}$ & $\begin{array}{l}\text { Positive } \\
\text { regime }\left(\beta^{p}\right)\end{array}$ & $\begin{array}{c}\text { Negative } \\
\text { regime }\left(\beta^{n}\right)\end{array}$ & Constant & \# of obs. & $\mathrm{R}^{2}$ \\
\hline \multicolumn{16}{|l|}{ Firm size class } \\
\hline 5-29 & $\begin{array}{c}0.1167 \\
(0.0061)\end{array}$ & $\begin{array}{l}0.0895 \\
(0.006)\end{array}$ & $\begin{array}{c}0.0367 \\
(0.0003)\end{array}$ & 399,650 & 0.0054 & $\begin{array}{l}-0.0466 \\
(0.006)\end{array}$ & $\begin{array}{l}-0.1301 \\
(0.006)\end{array}$ & $\begin{array}{c}0.0375 \\
(0.0003)\end{array}$ & 399,650 & 0.0043 & $\begin{array}{c}0.8377 \\
(0.0056)\end{array}$ & $\begin{array}{l}0.7747 \\
(0.006)\end{array}$ & $\begin{array}{r}-0.0005 \\
(0.0002)\end{array}$ & 399,650 & 0.2837 \\
\hline 30-99 & $\begin{array}{l}0.1327 \\
(0.009)\end{array}$ & $\begin{array}{l}0.0674 \\
(0.009)\end{array}$ & $\begin{array}{c}0.0415 \\
(0.0004)\end{array}$ & 115,028 & 0.0073 & $\begin{array}{l}-0.0542 \\
(0.009)\end{array}$ & $\begin{array}{l}-0.1234 \\
(0.009)\end{array}$ & $\begin{array}{c}0.0431 \\
(0.0004)\end{array}$ & 115,028 & 0.0060 & $\begin{array}{c}0.8154 \\
(0.0083)\end{array}$ & $\begin{array}{l}0.8056 \\
(0.008)\end{array}$ & $\begin{array}{c}0.0008 \\
(0.0004)\end{array}$ & 115,028 & 0.3586 \\
\hline $100-499$ & $\begin{array}{l}0.1240 \\
(0.009)\end{array}$ & $\begin{array}{c}0.0639 \\
(0.0087)\end{array}$ & $\begin{array}{c}0.0403 \\
(0.0004)\end{array}$ & 106,510 & 0.0072 & $\begin{array}{l}-0.0331 \\
(0.009)\end{array}$ & $\begin{array}{c}-0.1165 \\
(0.0086)\end{array}$ & $\begin{array}{c}0.0413 \\
(0.0004)\end{array}$ & 106,510 & 0.0051 & $\begin{array}{l}0.8468 \\
(0.008)\end{array}$ & $\begin{array}{c}0.8145 \\
(0.0074)\end{array}$ & $\begin{array}{c}0.0001 \\
(0.0003)\end{array}$ & 106,510 & 0.4326 \\
\hline 500-999 & $\begin{array}{c}0.1172 \\
(0.0077)\end{array}$ & $\begin{array}{l}0.0781 \\
(0.008)\end{array}$ & $\begin{array}{c}0.0392 \\
(0.0003)\end{array}$ & 112,769 & 0.0093 & $\begin{array}{r}-0.0122 \\
(0.0077)\end{array}$ & $\begin{array}{l}-0.0817 \\
(0.007)\end{array}$ & $\begin{array}{c}0.0391 \\
(0.0003)\end{array}$ & 112,769 & 0.0026 & $\begin{array}{c}0.8703 \\
(0.0068)\end{array}$ & $\begin{array}{l}0.8374 \\
(0.007)\end{array}$ & $\begin{array}{r}-0.0007 \\
(0.0003)\end{array}$ & 112,769 & 0.4774 \\
\hline over 1000 & $\begin{array}{r}0.1416 \\
(0.006) \\
\end{array}$ & $\begin{array}{c}0.0660 \\
(0.0059) \\
\end{array}$ & $\begin{array}{r}0.0415 \\
(0.0003) \\
\end{array}$ & 205,728 & 0.0093 & $\begin{array}{l}0.0014 \\
(0.006) \\
\end{array}$ & $\begin{array}{r}-0.0828 \\
(0.0058) \\
\end{array}$ & $\begin{array}{r}0.0423 \\
(0.0003) \\
\end{array}$ & 205,728 & 0.0020 & $\begin{array}{r}0.8612 \\
(0.005) \\
\end{array}$ & $\begin{array}{r}0.8458 \\
(0.0049) \\
\end{array}$ & $\begin{array}{r}0.0000 \\
(0.0002) \\
\end{array}$ & 205,728 & 0.4707 \\
\hline \multicolumn{16}{|l|}{ Industry } \\
\hline Manufacturing & $\begin{array}{l}0.0821 \\
(0.004)\end{array}$ & $\begin{array}{l}0.0434 \\
(0.004)\end{array}$ & $\begin{array}{c}0.0267 \\
(0.0002)\end{array}$ & 326,320 & 0.0048 & $\begin{array}{l}-0.0464 \\
(0.004)\end{array}$ & $\begin{array}{l}-0.1016 \\
(0.004)\end{array}$ & $\begin{array}{c}0.0294 \\
(0.0002)\end{array}$ & 326,320 & 0.0072 & $\begin{array}{l}0.8750 \\
(0.004)\end{array}$ & $\begin{array}{l}0.8501 \\
(0.004)\end{array}$ & $\begin{array}{c}0.0019 \\
(0.0002)\end{array}$ & 326,320 & 0.4816 \\
\hline Other service & $\begin{array}{l}0.1628 \\
(0.007)\end{array}$ & $\begin{array}{l}0.0970 \\
(0.006)\end{array}$ & $\begin{array}{c}0.0462 \\
(0.0003)\end{array}$ & 294,312 & 0.0091 & $\begin{array}{l}0.0150 \\
(0.007)\end{array}$ & $\begin{array}{l}-0.0936 \\
(0.006)\end{array}$ & $\begin{array}{c}0.0438 \\
(0.0003)\end{array}$ & 294,312 & 0.0013 & $\begin{array}{l}0.8497 \\
(0.006)\end{array}$ & $\begin{array}{l}0.8062 \\
(0.005)\end{array}$ & $\begin{array}{c}-0.0032 \\
(0.0002)\end{array}$ & 294,312 & 0.3422 \\
\hline Retail, Wholesale \& Restaurants & $\begin{array}{l}0.1282 \\
(0.009)\end{array}$ & $\begin{array}{l}0.0974 \\
(0.009)\end{array}$ & $\begin{array}{c}0.0521 \\
(0.0004)\end{array}$ & 185,419 & 0.0060 & $\begin{array}{l}-0.0617 \\
(0.009)\end{array}$ & $\begin{array}{l}-0.1274 \\
(0.009)\end{array}$ & $\begin{array}{c}0.0538 \\
(0.0004)\end{array}$ & 185,419 & 0.0045 & $\begin{array}{l}0.8139 \\
(0.008)\end{array}$ & $\begin{array}{l}0.7672 \\
(0.008)\end{array}$ & $\begin{array}{c}0.0004 \\
(0.0004)\end{array}$ & 185,419 & 0.2562 \\
\hline Construction & $\begin{array}{r}0.1357 \\
(0.013) \\
\end{array}$ & $\begin{array}{l}0.0930 \\
(0.013) \\
\end{array}$ & $\begin{array}{r}0.0334 \\
(0.0006) \\
\end{array}$ & 60,654 & 0.0101 & $\begin{array}{r}-0.0333 \\
(0.013) \\
\end{array}$ & $\begin{array}{l}-0.1243 \\
(0.013) \\
\end{array}$ & $\begin{array}{c}0.0347 \\
(0.0006) \\
\end{array}$ & 60,654 & 0.0049 & $\begin{array}{r}0.8274 \\
(0.013) \\
\end{array}$ & $\begin{array}{r}0.7740 \\
(0.013) \\
\end{array}$ & $\begin{array}{c}0.0001 \\
(0.0006) \\
\end{array}$ & 60,654 & 0.3277 \\
\hline \multicolumn{16}{|l|}{ period } \\
\hline 1997Q3-1998Q4 & $\begin{array}{c}0.1312 \\
(0.0105)\end{array}$ & $\begin{array}{l}0.0651 \\
(0.01)\end{array}$ & $\begin{array}{c}0.0371 \\
(0.0004)\end{array}$ & 88,597 & 0.0092 & $\begin{array}{c}-0.0074 \\
(0.0106)\end{array}$ & $\begin{array}{l}-0.1104 \\
(0.01)\end{array}$ & $\begin{array}{c}0.0370 \\
(0.0004)\end{array}$ & 88,597 & 0.0028 & $\begin{array}{c}0.8631 \\
(0.0097)\end{array}$ & $\begin{array}{l}0.8166 \\
(0.009)\end{array}$ & $\begin{array}{c}-0.0008 \\
(0.0004)\end{array}$ & 88,597 & 0.3638 \\
\hline 1999Q1-2001Q1 & $\begin{array}{c}0.1088 \\
(0.0099)\end{array}$ & $\begin{array}{l}0.0875 \\
(0.01)\end{array}$ & $\begin{array}{c}0.0399 \\
(0.0004)\end{array}$ & 117,225 & 0.0056 & $\begin{array}{c}-0.0381 \\
(0.0099)\end{array}$ & $\begin{array}{l}-0.0975 \\
(0.01)\end{array}$ & $\begin{array}{c}0.0412 \\
(0.0004)\end{array}$ & 117,225 & 0.0028 & $\begin{array}{c}0.8480 \\
(0.0085)\end{array}$ & $\begin{array}{l}0.8105 \\
(0.008)\end{array}$ & $\begin{array}{c}0.0000 \\
(0.0004)\end{array}$ & 117,225 & 0.3397 \\
\hline 2001Q1-2002Q2 & $\begin{array}{l}0.0684 \\
(0.017)\end{array}$ & $\begin{array}{c}0.0900 \\
(0.0168)\end{array}$ & $\begin{array}{c}0.0385 \\
(0.0008)\end{array}$ & 62,370 & 0.0038 & $\begin{array}{l}-0.0877 \\
(0.017)\end{array}$ & $\begin{array}{c}-0.0821 \\
(0.0169)\end{array}$ & $\begin{array}{c}0.0438 \\
(0.0008)\end{array}$ & 62,370 & 0.0031 & $\begin{array}{l}0.8565 \\
(0.015)\end{array}$ & $\begin{array}{c}0.8186 \\
(0.0148)\end{array}$ & $\begin{array}{c}0.0039 \\
(0.0007)\end{array}$ & 62,370 & 0.3212 \\
\hline 2002Q3-2007Q4 & $\begin{array}{c}0.1208 \\
(0.0063)\end{array}$ & $\begin{array}{l}0.0932 \\
(0.006)\end{array}$ & $\begin{array}{c}0.0418 \\
(0.0003)\end{array}$ & 283,000 & 0.0070 & $\begin{array}{c}-0.0247 \\
(0.0063)\end{array}$ & $\begin{array}{l}-0.0999 \\
(0.006)\end{array}$ & $\begin{array}{c}0.0412 \\
(0.0003)\end{array}$ & 283,000 & 0.0021 & $\begin{array}{c}0.8521 \\
(0.0057)\end{array}$ & $\begin{array}{l}0.8015 \\
(0.006)\end{array}$ & $\begin{array}{c}-0.0015 \\
(0.0002)\end{array}$ & 283,000 & 0.3228 \\
\hline 2008Q1-2009Q4 & $\begin{array}{r}0.1304 \\
(0.011) \\
\end{array}$ & $\begin{array}{c}0.0670 \\
(0.0112) \\
\end{array}$ & $\begin{array}{r}0.0406 \\
(0.0005) \\
\end{array}$ & 101,333 & 0.0067 & $\begin{array}{l}-0.0451 \\
(0.011) \\
\end{array}$ & $\begin{array}{r}-0.0924 \\
(0.0113) \\
\end{array}$ & $\begin{array}{c}0.0422 \\
(0.0005) \\
\end{array}$ & 101,333 & 0.0030 & $\begin{array}{l}0.8247 \\
(0.011) \\
\end{array}$ & $\begin{array}{r}0.8346 \\
(0.0105) \\
\end{array}$ & $\begin{array}{r}0.0004 \\
(0.0005)\end{array}$ & 101,333 & 0.3136 \\
\hline
\end{tabular}

Source: Authors' calculations based on Monthly Labour Survey. Standard errors are in parenthesis. 
Large establishments rely to a much greater extent on average hours adjustments to adjust total hours worked than small establishments, and particularly, when reducing total hours worked. Size does not appear to play a major role for the relationship between worker flows (hires and separations) and the growth rate of total hours worked. While small establishments tend to rely more strongly on reducing hires to reduce total hours worked than large establishments and more on reducing separation rates to increase total hours worked, this largely reflects the role of employment adjustment more generally in accommodating the role of total hours changes rather than the specific role of churning for adjusting employment.

The role of working time adjustments is most important in manufacturing. This is likely to reflect the relative importance of match-specific human capital in this sector. ${ }^{25}$ The retail, wholesale and restaurant sector makes relatively little use of working time adjustments and relatively more of employment adjustments. As churning is particularly high in this sector, the scope of reducing total hours worked by reducing hires and of increasing total hours worked by reducing separations is larger than in other sectors.

Changes in the hiring and separation behaviour of establishments over the business cycle tend to be relatively small. Hiring rates exhibit a weakly counter-cyclical behaviour as indicated from the intercepts. This reflects the greater importance of quits in booms and the resulting need for replacement hiring. Conversely, in recessions both quits and the need for replacement hires decline. The decline in hires was particularly strong in the 2001 and 2002 recession, leading to a significant increase in unemployment. By comparison, separation rates are relatively stable over the cycle. There is further some indication that worker flows (both hires and separations) have increased over time.

\section{Simulation analysis}

This section makes use of the micro-economic relationships documented in Section 5 to analyse the adjustment behaviour of Japanese establishment during the global financial crisis. More specifically, it compares the evolution of employment, hires and separations during the global financial crisis (2008Q4 to 2009 Q4) with that observed during the 1997 crisis (1997 Q2 to 1998 Q2). In contrast to the macro-level comparison in Figure 4, the analysis here explicitly takes account of i) changes in the micro-economic adjustment behaviour of establishments based on the average adjustment behaviour in each period ("technology effect"); ii) changes in the composition of establishments across sectors and firm-size

25 There is some indication that manufacturing establishments that reduce employment rely less on reducing replacement hiring (attrition) to reduce total hours worked than establishments in other industries. This most likely reflects the importance of employment adjustments for total hours changes in general rather that of churning for employment adjustments (Hellerstein et al., 1999). 
categories and the incidence of non-standard work ("composition effect”); and iii) differences in the nature of the economic downturn in terms of the distribution of total hours changes across establishments ("shock effect"). ${ }^{26}$ Table 5 summarises the results in terms of the cumulative rates over the first four quarters of each crisis episode.

Table 5. Decomposing the difference in labour input adjustment between the global financial crisis and the 1997 crisis

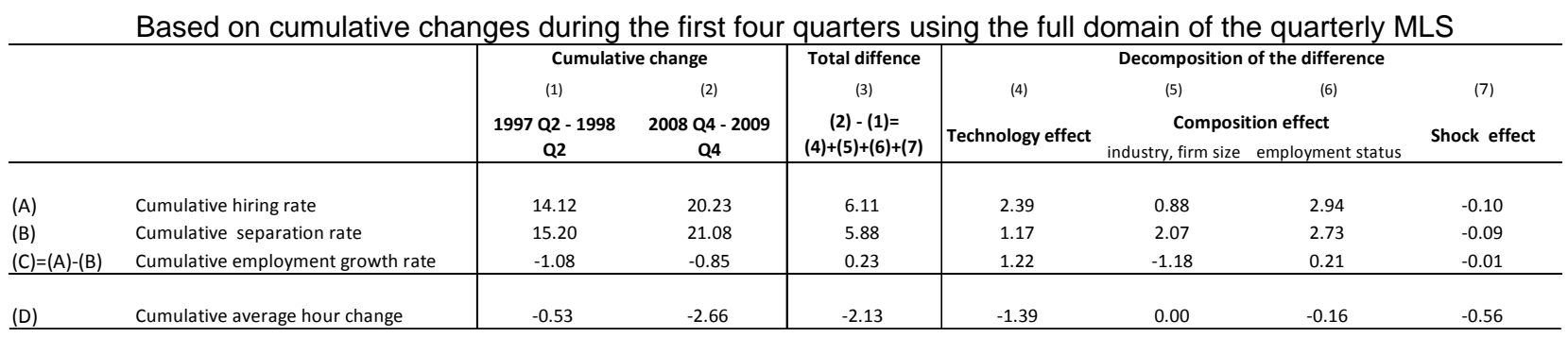

The first three columns of Table 5 describe the cumulative growth rates in hires, separations and employment based on equation 5 in the methodology section. Despite a much larger decline in aggregate demand during the global financial crisis, the cumulative declines in employment during the first four quarters of the two episodes were of similar magnitude and even slightly smaller during the global financial crisis (there is a small but positive difference of 0.2 in column 3 and row $\mathrm{C}$ ), while the cumulative decline in average hours worked was significantly larger during the first year of the global crisis (2.1 percentage points in column 3 and row $\mathrm{D}$ ). This is broadly consistent with the macro picture in Panel B of Figure 4.

The last four columns of Table 4 decomposes the differences in cumulative growth rates between the 1997 crisis and the global financial crisis into components that can be attributed to a technology, a composition, and a shock effect, following the approach described in Section 3. The decomposition results suggest that the relatively small/large employment/average hour response during the global financial crisis reflects the differential labour input behaviour of Japanese establishments during the global financial crisis compared with the 1997 crisis, but also the role of countervailing forces. While changes in the composition of workers and establishments $(-1.2+0.2==-1.0$ in column 5 and 6 row $\mathrm{C})$, have tended to increase the negative employment response, these have been more than offset by the technology effect which shifted the adjustment of labour input away from employment worked to average hours worked (1.2 in column 4 row $\mathrm{C}$ ). As a result, the decline in total employment during the global financial crisis is almost the same as

26 Given the endogeneity of changes in total hours worked, these effects should be interpreted in a statistical or accounting sense, and do not necessarily reflect causal relationships. 
that during the 1997 crisis. By contrast, the stronger response in average hours worked during the first year of the global financial crisis is not only the result of a technology effect but also to some extent of the greater reduction in labour demand and changes in the composition of the workforce.

The composition effect in the case of employment growth is largely driven by the increase in nonstandard work. Given the shock distribution and hiring/separation technologies, the increase in the incidence of non-standard work implies more adjustment on the employment margin and an increase in worker turnover due to both a higher hiring rate and a higher separation rate $(+2.9 /+2.7$ in column 6 row A and B). On the other hand, the compositional change in industry and firm size shifted the separations than the hirings, which is consistent to the dependence on more flexible technology in recent growing industries.

The role of the technology effect is more difficult to explain. While the technology effect in hires and separations may indeed reflect the impact of the labour market reforms in the late 1990s and early 2000s on the use of non-standard workers and hence worker turnover, one might equally have expected a greater role for employment adjustment during the global financial crisis. Actually, because the technological effect was larger for hiring than for separations, the opposite is observed. ${ }^{27}$ One reason why this pattern is not observed in practice may be related to the very different nature of the global financial crisis relative to the 1997 crisis and its impact on the expectations of managers about the persistence of the decline in aggregate demand. While both crisis episodes were triggered by events outside Japan, the 1997 crisis revealed major structural problems necessitating important permanent adjustments, whereas the impact of the global financial crisis was largely expected to be temporary, increasing incentives for labour hoarding by temporarily reducing working time (Hijzen and Venn, 2010). This effect should be captured by the technology effect in Table 7. However, an alternative explanation could be that this reflects a "honeymoon effect" in the transition period following the liberalisation of the market for temporary work as suggested by Boeri and Garibaldi (2007). Differentiating between these two explanations is not straightforward within the largely descriptive framework used in this paper and is left for future work.

\section{Concluding remarks}

This paper provides a detailed portrait of the micro-economic adjustment behaviour of Japanese establishments to labour demand shocks which provides the following key insights. First, Japanese employers rely to a very large extent on adjusting average hours changes. This is particularly important in

$27 \quad$ As a matter of fact, Japanese firms are increasingly considering hires from other firms in addition to new graduates. The share of new graduates in hiring declined from $20.5 \%$ in 1996 to $15.3 \%$ in 2012. 
the context of small labour demand shocks, but average hours adjustment remains sizeable also in the context of large total hours changes. Average hours changes account for about $80 \%$ of total hours adjustment in establishments reducing total hours worked by $5 \%$ and slightly more than half of total hours adjustment in establishments that reduce total hours worked by $50 \%$. Second, the incidence of nonstandard work has increased considerably in recent years, worker turnover is much higher among nonstandard workers than standard workers and the importance of working time adjustments tends to be less for non-standard workers. Taken together, this suggests that increased incidence of non-standard work should be associated with a stronger role for employment in labour input adjustment and higher levels of worker turnover.

Comparing the labour market experience during the global financial crisis with that observed during the 1997 crisis suggests that the employment response was relatively small despite the increase in the incidence of non-standard work and that worker turnover was very high. The limited employment response may reflect the temporary nature of the global financial crisis, an aspect that could not be explicitly controlled for in the present framework. While both crisis episodes were triggered by events outside Japan, the 1997 crisis revealed major structural problems necessitating making permanent adjustments, whereas impact of the global financial crisis was largely expected to be temporary, increasing incentives for labour hoarding by temporarily reducing working time. However, it is also possible that the subdued employment response may reflect the so-called "honeymoon effect" in the transitional period following the liberalisation of the market for temporary work. Differentiating between these two explanations is not straightforward within the largely descriptive framework used in this paper and is left for future work.

While the temporary nature of the global financial crisis is likely to account for a substantial part of the adjustment behaviour of Japanese establishments, this is not to say the changes in the composition of workers and establishments do not play an important role. Indeed, counterfactual simulations suggest that the employment response during the global financial crisis would have been even smaller had the incidence of non-standard work remained at the level observed during the 1997 crisis. This means that the apparent resilience of the Japanese labour market during the global financial crisis obscures important structural changes that are likely to have reduced labour market resilience once one takes account of the specific nature of the crisis. 


\section{References}

Aoki, M., (1990), “Toward an Economic Model of the Japanese Firm,” Journal of Economic Literature, Vol. 28, pp. 1-27.

Abowd, J., P. Corbel, and F. Kramarz, (1999), "The Entry and Exit of Workers and the Growth of Employment: An Analysis of French Establishments," The Review of Economics and Statistics, Vol.81, pp.170-187.

Abraham, K. G. and S. N. Houseman, (1994), "Does Employment Protection Inhibit Labor Market Flexibility? Lessons from Germany, France and Belgium,” in R. M. Blank, ed., Social Protection versus Economic Flexibility, Chicago: University of Chicago Press, pp. 59-93.

Ariga, K. and R. Kambayashi, (2010), "Employment and wage adjustments at firms under distress in Japan: An analysis based upon a survey,” Journal of the Japanese and International Economies, Vol.24, pp.213-235.

Bentolila, S., P. Cahuc, J. J. Dolado and T. Le Barbanchon, (2014), “Unemployment and Temporary Jobs in the Crisis: Comparing France and Spain”, Economic Journal, forthcoming.

Bellman, L., H. D. Gerner, and R. Upward, (2011), “Job and Worker Turnover in German Establishments,” IZA Discussion Paper Series, No. 6081.

Blanchard, O. J. and A. Landier (2002), “The Perverse Effects of Partial Labor Market Reform: Fixed Duration Contracts in France”, Economic Journal 112, 214-244.

Boeri, T., (2011), “Institutional reforms and Dualism in European Labor Markets,” in O. Ashenfelter \& D. Card (eds.), Handbook of Labor Economics, Volume 4b, Chapter 13, pp. 1173-1236.

Bognanno, M. L. and L. Delgado, (2008), “Job Displacement Penalties in Japan”, Research in Labor Economics, Vol. 28, pp.225-250.

Caballero, R., E. Engel, and J. Haltiwanger, (1997), “Aggregate Employment Dynamics: Building From Microeconomic Evidence,” American Economic Review, Vol.87, pp.115-137.

Cahuc, P. and F. Postel-Vinay (2002), "Temporary Jobs, Employment Protection and Labor Market Performance”, Labour Economics, 9, 63-91.

Davis, S. J., R. J. Faberman and J. Haltiwanger, (2006), “The Flow Approach to Labor Markets, MicroMacro Links, and the Recent Downturn,” Journal of Economic Perspectives, Vol.20, pp.3-26.

Davis, S. J., R. J. Faberman and J. Haltiwanger, (2011), "Labor Market Flows in the Cross Section and Over Time,” NBER Working Papers No. 17294.

Fabling, R. and D. Maré, (2012), “Cyclical Labour Market Adjustment in New Zealand: The Response of Firms to the Global Financial Crisis and its Implications for Workers,” Working Papers 12_04, Motu Economic and Public Policy Research. 
Freeman, R. B. and M. L. Weitzman, (1986), "Bonuses and Employment in Japan,” Journal of the Japanese and International Economies, Vol.1, pp.168-194.

Gal, P. N., A. Hijzen, and W. Zoltan, (2013), “The Role of Institutions and Firm Heterogeneity for Labour Market Adjustment: Cross-Country Firm-Level Evidence,” IZA Discussion Papers 7404, Institute for the Study of Labor (IZA).

Hamermesh, D. (I993). Labor Demand. Princeton, NJ: Princeton University Press.

Hashimoto, M. and J. Raisian, (1985), "Employment Tenure and Earnings Profiles in Japan and the United States,” American Economic Review, Vol.75, pp.721-35.

Hellerstein, J.K., D. Neumark and K.R. Troske (1999), “Wages, Productivity, and Worker Characteristics: Evidence from Plant-Level Production Functions and Wage Equations”, Journal of Labor Economics, Vol. 17(3), pages 409-446.

Hijzen, A. and D. Venn, (2010), “The Role of Short-Time Work Schemes during the 2008-09 Recession,” OECD Social, Employment and Migration Working Papers 115, OECD Publishing.

Kambayashi, R. and T. Kato, (2011), "Japanese Employment System after the Bubble Burst: New Evidence,” in Hamada, Kashyap, Kuroda, and Weinstein, eds., Japan's Bubble, Deflation, and Stagnation, MIT Press, pp.217-262.

Kambayashi, R. and T. Kato, (2012), “Good Jobs, Bad Jobs, and the Great Recession: Lessons from Japan’s Lost Decade,” June 2012, IZA Discussion Paper Series No. 6666.

Kuroda, S. and I. Yamamoto, (2013), “Firms' demand for work hours: Evidence from matched firm-worker data in Japan,” Journal of the Japanese and International Economies, Vol.29, pp.57-73.

Lazear, E. (1981), “Agency, earnings profiles, productivity, and hours restrictions,” American Economic Review, Vol.71, pp.606-620.

OECD (2010), Employment Outlook, Paris.

OECD (2011), OECD Economic Surveys: Japan, Paris.

OECD (2012), Employment Outlook, Paris.

Okudaira, H., F. Ohtake, K. Kume, and K. Tsuru, (2013), "What does a temporary help service job offer? Empirical suggestions from a Japanese survey,” Journal of the Japanese and International Economies, Vol. 28, pp.37-68.

Steinberg, C. and M. Nakane, (2011), “To Fire or to Hoard? Explaining Japan's Labor Market Response in the Great Recession,” IMF Working Paper (Washington: International Monetary Fund).

Teruyama, H. and Y. Genda, (2009), "Some Facts on a Link between Worker Flows and Job Flows (in Japanese),” ESRI Discussion paper series No. 208. 